\title{
THE EMPLOYER'S OBLIGATION OF EQUAL TREATMENT IN EMPLOYMENT RELATIONSHIP ESTABLISHED UNDER TURKISH LABOUR ACT OF TURKEY (ACT NO. 4857)
}

\author{
DOI: 10.17261/Pressacademia.2021.1416 \\ PAP- V.13-2021(5)-p.22-27
}

\section{Muhammed Turkalp Seckin}

Istanbul Technical University, Faculty of Management, Department of Management Engineering, Istanbul, Turkey. seckint@itu.edu.tr, ORCID: 0000-0002-0866-4536

\section{To cite this document}

Seckin, M. T. (2021). The employer's obligation of equal treatment in employment relationship established under Turkish labout act (Act No. 4857). PressAcademia Procedia (PAP), V.13, 22-27.

Permanent link to this document: http://doi.org/10.17261/Pressacademia.2021.1416

Copyright: Published by PressAcademia and limited licensed re-use rights only.

\section{ABSTRACT}

Purpose- The aim of this study is examining the regulations regarding the employer's obligation of equal treatment stated in Labour Act of Turkey (Act No. 4857), Turkish Constitution and The Human Rights and Equality Institution of Turkey Act and clarifying the differences between prohibition of discrimination and the employer's obligation of equal treatment in general manner which are component of the employer's obligation of equal treatment

Methodology- The regulations stated in Labour Act of Turkey (Act No. 4857), Turkish Constitution and The Human Rights and Equality Institution of Turkey Act will be analyzed in comparison, and also the Supreme Court decisions regarding the subject will be mentioned.

Findings- Prohibition of discrimination is arising from Labour Act of Turkey (Act No. 4857) article 5 and the employer's obligation of equal treatment in general manner is arising from Turkish Constitution article 10. Also, the scope of prohibition of discrimination regulation stated in The Human Rights and Equality Institution of Turkey Act is limited in terms of Institution practice.

Conclusion- Prohibition of discrimination and the employer's obligation of equal treatment in general manner are different phenomenon in terms of their characteristics and results of their breach.

Keywords: Principle of equality, obligation of equal treatment, prohibition of discrimination, discrimination compensation, employee JEL Codes: K31, K41

\section{SAYILI iş KANUNU KAPSAMINDA KURULAN iş ILIŞKILERINDE işVERENIN EŞiT DAVRANMA BORCU}

\section{ÖZET}

Amaç - Bu çalışmanın amacı işverenin eşit davranma borcu ile ilgili olarak Anayasa, 4857 sayılı Iş Kanunu ile 6701 sayılı Türkiye İnsan Hakları ve Eşitlik Kurumu Kanunu'nda yer alan düzenlemelerin incelenmesi ve işverenin eşit davranma borcunun kapsamını oluşturan ayrımcılık yasağı ile işverenin genel anlamda eşit davranma borcu arasındaki farkın açıklığa kavuşturulmasıdır.

Yöntem - Anayasa, 4857 sayııı İş Kanunu ve 6701 sayılı Türkiye İnsan Hakları ve Eşitlik Kurumu Kanunu'nda yer alan düzenlemeler karşılaştırmalı olarak ele alınacak, aynı zamanda konu ile ilgili verilmiş olan Yargıtay kararlarına da değinilecektir.

Bulgular- 4857 sayııı iş̧ Kanunu madde 5'te ayrımcılık yasağı düzenlenirken, işverenin genel anlamda eşit davranma borcu kaynağını Anayasa madde 10'dan almaktadır. 6701 sayııı Türkiye İnsan Hakları ve Eşitlik Kurumu Kanunu'nda yer alan ayrımclık yasağına ilişkin düzenlemelerin kapsamı ise Kurum uygulaması ile sınırlıdır.

Sonuç- Ayrımcılık yasağı ile işverenin genel anlamda eşit davranma borcu, nitelikleri ve ihlal edilmelerinin sonuçları bakımından farklı kavramlardır.

Anahtar Kelimeler: Eşitlik ilkesi, eşit davranma borcu, ayrımcılık yasağı, ayrımcılık tazminatı, işçi JEL Kodları: K31, K41

\section{GíRiş}

Issverenin eşit davranma borcu "ișverenin haklı nedenler bulunmaksızın işçiler arasında farklı davranmaması, yani; haksız ayrımda bulunmaması, keyfi davranışlardan kaçınması; haklı nedenler varsa ayrımda bulunması, farklı davranması yükümlülüğünü ifade etmektedir" şeklinde tanımlanmaktadır (Mollamahmutoğlu/Astarlı/Baysal, 2014: 722-723). Doktrinde eșit davranma borcunun iki ayrı borcun bileşeni olduğu ifade edilmektedir. Temel hak ve özgürlükler bakımından "ayrımcılık yasağı"; ayrımclık yasağı dışında kalan alanlarda işverenin 
yönetim hakkını ilgilendiren uygulamalar bakımından ise "genel anlamda eşit davranma borcu" eşit davranma borcunun kapsamını oluşturmaktadır (Doğan Yenisey, 2006: 66). işverenin eşit davranma borcu tüm işçiler bakımından mutlak şekilde ayrım yapılmaması şeklinde algılanmamalı, objektif olarak farklı davranılması gereken hallerde yine de eşit davranmanın eşitsizliğe yol açacağı göz önünde bulundurulmalıdır (Mollamahmutoğlu/Astarlı/Baysal, 2014: 722). Ayrımcılık yasağının konusunu temel hak ve özgürlükler kapsamında insanın insan olmasından kaynaklanan ve değiştirilemeyecek ırk, cinsiyet, renk, vb. gibi özellikler ya da değiştirilmesi beklenemeyecek siyasal görüş, felsefi inanç, din, vb. görüşler oluştururken (Süzek, 2019: 440); işverenin genel anlamda eşit davranma borcunun konusunu ücret, ikramiye, prim, sosyal yardım vb. gibi haklar; işverenin yönetim yetkisi kapsamında giriş çıkış kontrolü yapması, sigara yasağı, fazla çalışma yaptırılması, angarya işlerin verilmesi, işin dağıtımı, iş ve işyerinin belirlenmesi, disiplin cezası, meslekte yükselme gibi hususlar oluşturmaktadır (Tunçomağ/Centel, 2015: 145; Tuncay, 1982: 160; Aktay/Arıcı/Senyen Kaplan, 2012: 149). Belirtmek gerekir ki eşit davranma borcunun temelinde insan onuru bulunduğundan söz konusu eşitlik anlayışı kötüde eşitleme şeklinde değerlendirilmemelidir (Yıldız, 2008: 66).

İşverenin tabi olduğu ayrımcılık yasağı bakımından hukukumuzda yer alan pozitif düzenlemeler Anayasa madde 10 ve 11 'de; 4857 sayılı İş Kanunu madde 5, 12, 13 ve 99'da; 6701 sayılı Türkiye İnsan Hakları ve Eşitlik Kurumu Kanunu madde 3, 4, 5 ve 6'da yer almaktadır. İşverenin genel anlamda eşit davranma borcuna ilişkin uygulamalar da kaynağını Anayasa madde 10, 11 ve 55'te yer alan düzenlemelerden almaktadır (Tuncay, 1982: 59; Süzek, 2019: 440). Her ne kadar İK madde 5'in başlığı "eşit davranma ilkesi” olsa da madde metninde ayrımcılık yasaklarına yer verilmiştir. İK madde 5'in başlığının "eşit davranma ilkesi olması", ayrımcılık yasağı ile işverenin genel anlamda eşit davranma borcunun karıştırılmasına neden olabilmektedir. Bu durum, işverenin genel anlamda eşit davranma borcunun ihlali halinde de ík madde 5'te ayrımcılık yasağının sonucu olarak öngörülen ayrımcılık tazminatının işçiler tarafından talep edilmesine ve bu talebin kabul edildiği ilk derece mahkemesi kararlarının bozulmasına neden olabilmektedir. Aşağıda eşit davranma borcunun yapısını oluşturan iki farklı hukuki yapı, temellerini oluşturan farklı pozitif düzenlemeler ile "ayrımcılık yasağı" ve "işverenin genel anlamda eşit davranma borcu" başlıkları altında açıklanmaya çalışılacaktır. Ayrıca ayrımcılık yasağı başlığı altında Türkiye İnsan Hakları ve Eşitlik Kurumu Kanunu ile getirilen düzenlemelerin mahiyeti hakkında da değerlendirmeler yapılacaktır. Belirtmek gerekir ki her farklı hukuki düzenlemenin içinde yer alan farklı tanım ve yasaklar, yer aldıkları düzenlemenin uygulanması yönünden önem arz etmektedirler (Benzer yönde görüş için bkz. Çelik/Caniklioğlu/Canbolat, 2019: 425).

\section{AYRIMCILIK YASAĞI}

\subsection{Türkiye Cumhuriyeti Anayasası'nda Yer Alan Düzenleme}

Anayasa madde $10^{\prime}$ da "herkes, dil, ırk, renk, cinsiyet, siyasi düşünce, felsefi inanç, din, mezhep ve benzeri sebeplerle ayrım gözetilmeksizin kanun önünde eşittir" düzenlemesi yer almaktadır. Anayasa madde 11'de yer alan "Anayasa hükümleri, yasama, yürütme ve yargı organlarını, idare makamlarını ve diğer kuruluş ve kişileri bağlayan temel hukuk kurallarıdır" hükmü uyarınca Anayasa madde 10'un devlet-birey arasındaki ilişkiyi düzenleyen dikey etkisinin yanında aynı zamanda özel hukuk kişileri arasındaki ilişkilere uygulanmasını gerektiren yatay etkisinin de olduğu kabul edilmelidir (Öden, 2003: 154-157; Süzek, 2019: 442). Böylelikle Anayasa'da yer alan eşitlik ilkesi, sahip olduğu yatay etki gereğince yalnızca kamu hukukuna ilişkin bir düzenleme olmayıp özel hukuk kişileri bakımından da bağlayıcıdır (Ulucan, 2013: 372).

\subsection{Sayılı İş Kanunu'nda Yer Alan Düzenleme}

\subsubsection{Kapsamı}

İş Kanunu madde 5/1'de "İş ilişkisinde dil, ırk, renk, cinsiyet, engellilik, siyasal düşünce, felsefi inanç, din ve mezhep ve benzeri sebeplere dayalı ayrım yapılamaz" hükmü yer almaktadır. Ayrımcılık yasağı İ madde 5 ile İş Kanunu’nda pozitif düzenlemeye kavuşmakla kalmayıp, aynı zamandan genel hükümler arasında düzenlendiğinden İş Hukukunun temel ilkelerinden biri haline gelmiştir (Doğan Yenisey, 2005: 974975). Madde metninde yer alan "ve benzeri sebeplerle" ifadesi nedeniyle sayılan hallerin sınırlayıcı olmadığı görülmektedir. Bu bağlamda örneğin, işçilerin genetik ayrımcılığa maruz kalmasının da yasak kapsamında olduğunu söylemek mümkündür (Taşdemir, 2020: 973). ík madde 5 'in başlığı her ne kadar eşit davranma ilkesi olsa da, maddede ayrımcılık yasağı kapsamında düzenlemeler yapıldığı görülmektedir (Yıldız, 2008: 63; Süzek, 2019: 441-442). Ancak doktrinde İK madde 5'in kapsamına genel anlamda eşit davranma borcunun da girdiğini savunan bir görüş de yer almaktadır (Keser, 2004: 26; Kaya, 2014: 1 vd.). í madde 5/6'da ayrımcılık tazminatı düzenlenmiş ancak söz konusu tazminatın yalnızca iş ilişkisinde ve iş ilişkisinin sona ermesi halinde söz konusu olacağı hüküm altına alınmıştır. Bu nedenle her ne kadar İK madde $5 / 3$ 'te işe alımlarda cinsiyet veya gebelikten dolayı ayrımcılık yapılamayacağı belirtilmişse de bu hükmün ihlali halinde ayrımcılık tazminatı talep edilemeyecektir (Baysal, 2010: 63). İ madde 5'in başlığı eşit davranma borcu olmakla birlikte madde metninde 2. fıkra dışında ayrımcılık yasağına ilişkin düzenlemeler yer almaktadır. Bu nedenle madde metninde genel anlamda eşit davranma borcunun düzenlenmiş olduğunu söylemek mümkün değildir (Süzek, 2019: 441; Sur, 2017: 36; Nazlı, 2016: 572). Her ne kadar ík madde 5'te genel anlamda eşit davranma borcu düzenlenmemiş olsa da, yukarda belirtildiği üzere Anayasa madde 10'da yer alan düzenleme, Anayasa madde 11 uyarınca özel hukuk kişileri arasında yatay düzeyde de uygulanmalıdır. Bu nedenle iş ilişkisi kapsamında işverenlerin genel anlamda eşit davranma borcu da bulunmaktadır (Süzek, 2019: 442). Ayrımcılık yasaklarında eşit davranma borcu az sayıdaki istisnalar haricinde mutlaktır, genel anlamda eşit davranma borcunun mutlak olmadığı kabul edilmektedir. İşverenin haklılaştırmak suretiyle işverenin genel anlamda eşit davranma borcu bağlamında işçilere farklı muamelede bulunması mümkündür (Çelik/Caniklioğlu/Canbolat, 2019: 418). Ancak ayrımcılık yasaklarında bu haklılaştırma çok daha zordur. Bu hususta İK madde 5/3 örnek olarak gösterilebilir (Kayaalp, 2019: 84).

Ayrımcılık nedenlerinin kapsamı ile ilgili olarak Yargıtay HGK'nın 2020 yılında vermiş olduğu bir karar özel olarak değerlendirilmelidir. Karara konu olayda ücretlerini alamayan işçilerin içinden bir grup icra yoluna başvurmuştur. İşveren ise yalnızca icraya başvurmayan iş̧̧ilerin ücretini ödemiştir. Bunun üzerine ücretlerini alamayan işçiler ayrımcılık tazminatı talebinde bulunmuşlardır. Yargıtay HGK uyuşmazlık ile ilgili vermiş olduğu kararda davalı işverenin, aleyhine icra takibi başlatan iş̧̧ilere ücret ödemesi yapmayıp, hakkında icra takibi başlatmayan işçilere ücret ödemesi yapmak suretiyle ayırımcılık yaptığı iddiası, temel hak ve hürriyetler arasında yer alan hak arama özgürlüğünün kullanılması bakımından çalışanlar arasında ik madde 5 uyarınca ayırımcılık yapıldığı şeklinde nitelendirilmesi gerektiğine hükmetmiştir (Yargıtay 
HGK'nın25.02.2020 tarih ve 2016-370/201 sayılı kararı, Lexpera). Kanaatimizce Anayasa'da yer alan temel hakların ihlali halinde ayrımcılık tazminatına hükmedileceğinin kabulü halinde örneğin, yıllık ücretli izinleri kullandırılmayan işçilerin de Anayasa madde 50/3'te yer alan dinlenme hakkı uyarınca ayrımcılık tazminatı talep edebilmeleri mümkün hale gelecektir. İ madde 5/1'de yer alan "iş ilişkisinde" ve madde 5/6' da yer alan "iş ilişkisinde ve sonra ermesinde" ibareleri nedeniyle ík madde 5'te düzenlenen ayrım yasaklarının işe alım sürecini kapsamadığı ifade edilmektedir. Her ne kadar IK madde $5 / 3$ 'te işe alım sürecinde cinsiyet ve gebelik nedeniyle ayrımcılık yapılamayacağı hükmü yer alsa da, bu hükmün ihlali İK madde 5/6' da herhangi bir yaptırıma bağlanmamış olduğundan, ayrımcılık tazminatı yönünden etkisi bulunmamaktadır (Süzek, 2019: 444-445; karş. Doğan Yenisey, 2006: 67). Ancak ík madde 99/1 uyarınca cinsiyet ve gebelik nedeniyle işe alımlarda yapılan ayrımcılık nedeniyle işverene idari para cezası verilmesi mümkündür.

İs sözleşmesinin feshinde işverenin genel anlamda eşit davranma borcunun bulunup bulunmadığı tartışmalı olmakla birlikte ayrımcılık yasaklarının ihlal edilemeyeceği açıktır (Sur, 2017: 42). İşçinin davranış veya yeterliliğine dayanan fesihlerde işverenin genel anlamda eşit davranma borcu olduğu kabul edilmelidir. Örneğin, işyerinde yaşanan bir kavgaya karışan işçilerden bazılarının iş sözleşmesi feshedildiği takdirde, diğer işçilerin sözleşmelerinin neden feshedilmediği hususunda işveren haklı bir nedene dayanmalıdır (Aynı yönde bkz. Yargıtay 9. HD’nin 18.09.2013 tarih ve 2011-23715/22926 sayılı kararı, Lexpera; karşı görüşte Çelik/Caniklioğlu/Canbolat, 2019, 422). Diğer yandan kavganın yaşanmasında işçilerden bir bölümü daha az kabahatli ise, bu durumda onların iş sözleşmesini feshetmek de hakkaniyete uygun olmayacaktır (Süzek, 2019: 451-453; Kandemir/Yardımcıoğlu, 2014: 29). İşletme gerekleri ile fesihte hangi işçilerin çıkarılacağı işverenin takdirinde olmakla birlikte (Mollamahmutoğlu/Astarlı/Baysal, 2019: 193) eşit davranma ilkesi gereğince işten çıkarılacak işçilerin seçiminde tutarlılık ve keyfilik denetimi yapılmalıdır (Süzek, 2019: 453-454; Mollamahmutoğlu/Astarlı/Baysal, 2019: 199).

\subsubsection{Hükme Aykırıı̆ı̆ın Sonuçları}

IK madde 5/6' da işverenin ayrımcı davranışına maruz kalan işçinin 4 aya kadar ücreti tutarında ayrımcılık tazminatı ile yoksun bırakıldığı hakları talep edebileceği düzenlenmiştir. Düzenlemede 2821 sayılı STiSK madde 31 'in, günümüzdeki karşılığıyla madde 25 'in saklı olduğu ifade edilmiştir. Ayrımcılık tazminatı çıplak ücret üzerinden hesaplanmalıdır. Hesaplamada ihlalin ağırlığı, işçinin kıdemi gibi hususlar göz önünde bulundurulmalıdır (Yargıtay 9. HD’nin 15.05.2019 tarih ve 2016-1423/11167 sayılı kararı, Kazancı). Ayrımcılık tazminatını miktarının sözleşme ile azaltılması mümkün olmamakla birlikte iş sözleşmesi veya toplu iş sözleşmesi ile artırılmasında bir engel bulunmamaktadır (Mollamahmutoğlu/Astarlı/Baysal, 2014: 740). Ayrımcılık yasağının ihlalinde işverenin niyetinin önemi bulunmayıp, davranışın mağdur üzerinde etkisi değerlendirilmektedir (Çelik/Caniklioğlu/Canbolat, 2019: 327). Ayrımcılık tazminatının talep edilebilmesi için iş sözleşmesinin feshedilmiş olması gerekmemektedir. Ayrımcılık tazminatı talebinde zamanaşımı süresi ile ilgili olarak ikili bir ayrım göze çarpmaktadır. İK ek madde 3 uyarınca ayrımcılık nedeniyle iş sözleşmesinin feshi söz konusu ise 5 yıl, iş sözleşmesi feshedilmemiş ise ayrımcı davranış tarihinden itibaren 10 yıllık zamanaşımı süresi söz konusudur (Süzek, 2019: 455-456). Ayrıca ayrımcılık tazminatı haricinde İK madde 99'da İK madde 5'e aykırılık halinde idari para cezası öngörülmüştür

Sendikal nedenle ayrımcılığın sonucu olarak sendikal tazminat öngörülmüş olduğundan ayrıca İ madde 5 uyarınca ikinci defa tazminata hükmedilmesi mümkün değildir (Yargıtay 22. HD’nin 12.07.2012 tarih ve 13064/16519 sayılı kararı, Kazancı). Yargıtay ayrımcılık yasağını ihlal eden davranışın feshin geçersizliği noktasında ve işe başlatmama tazminatının miktarı belirlenirken tartışıldığı, zaten ayrımcılık teşkil eden fesih nedeninin geçersiz kabul edildiği, bu nedenle işe başlatmama tazminatı yanında ayrıca ayrımcılık tazminatına hükmedilmemesi gerektiği görüşündedir (Yargıtay 9. HD’nin 17.09.2015 tarih ve 18355/26031 sayılı kararı, Lexpera). Ancak bizim de katıldığımız görüş uyarınca işe başlatmama tazminatı ile ayrımcılık tazminatının düzenleniş amaçları farklıdır ve ayrı ayrı talep edilebilmeleri gerekmektedir (Süzek, 2019: 457; Mollamahmutoğlu/Astarlı/Baysal, 2019: 199). Diğer yandan Yargıtay, aynı amaca hizmet ettikleri gerekçesiyle kötüniyet tazminatı ile ayrımcılık tazminatının birlikte istenemeyeceği, hangi tazminata hükmedilmesi işçinin lehine ise yalnızca o tazminat talebinin kabul edilmesi gerektiği görüşündedir (Yargıtay 22. HD’nin 27.03.2018 tarih ve 2015-28332/7866 sayılı kararı, Lexpera; karşı görüşte Süzek, 2019: 457; Mollamahmutoğlu/Astarlı/Baysal, 2019: 199; Kandemir/Yardımcıoğlu, 2014: 38).

\subsection{Sayılı Türkiye İnsan Hakları ve Eşitlik Kurumu Kanunu’nda Yer Alan Düzenleme}

\subsubsection{Kapsamı}

6701 sayılı Kanun madde 3'te eşitlik ilkesi ve ayrımcılık yasağı başlığı altında "bu kanun kapsamında cinsiyet, ırk, renk, dil, din, inanç, mezhep, felsefi ve siyasi görüş, etnik köken, servet, doğum, medeni hâl, sağlık durumu, engellilik ve yaş temellerine dayalı ayrımcılık yasaktır" düzenlemesi yer almaktadır. Madde metninde ayrımcılık yasağına ilişkin bir düzenleme söz konusudur. Yine 6701 sayılı Kanun madde 6/1 uyarınca "Işveren veya işveren tarafından yetkilendirilmiş kişi; işverenin çalışanı veya bu amaçla başvuran kişi, uygulamalı iş deneyimi edinmek üzere bir işyerinde bulunan veya bu amaçla başvuran kişi ve herhangi bir sıfatla çalışmak ya da uygulamalı iş deneyimi edinmek üzere işyeri veya iş ile ilgili olarak bilgi edinmek isteyen kişi aleyhine, bilgilenme, başvuru, seçim kriterleri, işe alım şartları ile çalışma ve çalışmanın sona ermesi süreçleri dâhil olmak üzere, işle ilgili süreçlerin hiçbirinde ayrımcılık yapamaz". Bu noktada belirtmek gerekir ki ayrımcılık yasağı kapsamına işe alım süreci de dahil edilmiştir. Nitekim Türkiye İnsan Hakları ve Eşitlik Kurumu’nun 2020/176 sayılı kararında iş başvurusunun hamileliği nedeniyle reddedildiği nedeniyle Kanun madde 17/2 uyarınca öncelikle işverenden düzeltilmesini talep ettiği, 30 gün içinde kendisine dönüş yapılmaması üzerine Kurum'a başvuru yapıldığı, Kurum'un değerlendirme sonucunda başvurucunun talebini haklı bularak ilgili firmaya idari para cezası verdiği görülmektedir. Madde $6 / 2$ 'de “Birinci fıkra iş ilanı, işyeri, çalışma şartları, mesleki rehberlik, mesleki eğitim ve yeniden eğitimin tüm düzeylerine ve türlerine erişim, meslekte yükselme ve mesleki hiyerarşinin tüm düzeylerine erişim, hizmet içi eğitim, sosyal menfaatler ve benzeri hususları da kapsar" şeklinde ayrımcılık yasağını daha da genişletilmiştir. Nitekim Türkiye İnsan Hakları ve Eşitlik Kurumu'nun 2018/97 sayılı kararında bir firmanın iş ilanında yer alan ayrımcı ifadelerin Kurum tarafından resen incelemeye tabi tutulduğu ve neticesinde ilgili firmaya idari para cezası uygulandığı görülmektedir. Kanun madde 9/1/g uyarınca Kurum’un ayrımcılık yasağı ihlallerini şikayet olmadan resen inceleme yetkisi bulunmaktadır. 


\subsubsection{Kurum’a Başvuru Usulü}

6701 sayılı Kanun madde 17'de ayrımcılık yasağı ihlalinden zarar gördüğü iddiasında bulunan her gerçek ve tüzel kişinin Türkiye İnsan Hakları ve Eşitlik Kurumu'na başvurabilecekleri düzenlenmiştir. Ancak 6701 sayılı Kanun madde 17/5 uyarınca IK madde 5 kapsamına giren ayrımcılık iddialarına ilişkin başvurular, İK ve ilgili mevzuatta belirlenen şikayet usulleri izlendikten sonra herhangi bir yaptırım kararı alınmadığı hallerde yapılabilecektir. Eski İK madde $91 / 2$ 'de iş sözleşmesi sona eren işçilerim iş sözleşmesinden doğan alacakları için il müdürlüklerine şikayet edebilecekleri düzenlenmişti. 7036 sayılı yasa ile 2017 tarihinde bu düzenleme kaldırılmıştır. Mevcut düzenlemede ík madde $91 / 1$ uyarınca iş sözleşmesi devam eden işçilerin şikayetlerinin iş müfettişleri tarafından yapılan teftiş faaliyeti kapsamına alınması mümkündür. İşçinin başvurusu reddedildiği veya cevapsız kaldığı takdirde işçi Kurum'a başvuru yapabilecektir (Süzek, 2019: 463). Doktrinde bu düzenlemenin diğer mevzuat hükümlerine tabi çalışanlar ile ik'ya tabi çalışanlar arasında ayrımcılık oluşturduğu ifade edilmiştir (Ünal, 2018: 509). 6701 sayılı Kanun madde 17/2 uyarınca iş̧̧ilerin Kurum'a başvuru yapmadan önce işverene başvurarak ihlalin giderilmesini talep etmeleri gerekmektedir. 30 gün içinde sonuç alınamadığı takdirde Kurum'a başvurulması mümkün hale gelmektedir. Ancak düzenlemeden, telafisi güç ve imkansız zararlar doğabilecek durumlarda işverene başvurulmasının gerekmediği anlaşılmaktadır. 6701 sayılı Kanun yürürlüğe girdiği 20.04 .2016 tarihinden sonra meydana gelen ayrımcılık yasağı ihlalleri bakımından uygulanmalıdır (farklı ihtimallerin değerlendirilmesi için bkz. Sarıbay Öztürk, 2017: 134-137)

\subsection{3. Öngörülen Hukuki Yaptırım}

6701 sayılı Kanun madde 25’te idari para cezası yaptırımı öngörülmüştür. Hükme göre "ayrımcılık yasağının ihlali halinde, bu ihlalin etki ve sonuçlarının ağırlığı, failin ekonomik durumu ve çoklu ayrımcılığın ağırlaştırıcı etkisi dikkate alınarak ihlalden sorumlu olan kamu kurum ve kuruluşları, kamu kurumu niteliğindeki meslek kuruluşları, gerçek kişiler ve özel hukuk tüzel kişileri hakkında bin Türk lirasından on beş bin Türk lirasına kadar idari para cezası uygulanacaktır". İşçinin Kurum'a başvurusu neticesinde işverene yalnızca idari para cezası verilecek olması işçinin hak kaybının giderilmesinde fayda sağlamayacaktır. Ancak Kanun madde 18/3 uyarınca tarafların uzlaşabilmesi ve uzlaşma neticesinde mağdura tazminat ödenebilmesi mümkündür. Bu durumda kanaatimizce uzlaşmayı kabul eden işçinin ayrıca İ madde 5 uyarınca ayrımcılık tazminatı talebi hakim tarafından reddedilmelidir.

\section{3. İşverenin Genel Anlamda Eşit Davranma Borcu}

\subsection{Genel olarak}

Anayasa madde 10 metni incelendiğinde maddenin yalnızca ırk, din, cinsiyet gibi temel hak ve özgürlükle ilgili ayrım yasaklarının değil, aynı zamanda genel anlamda eşit davranma borcunun da kaynağını oluşturduğunu söylemek mümkündür (Süzek, 2019: 441). Şöyle ki, Anayasa madde 10, iki ayrı önermenin birleşiminden oluşmaktadır. Madde metninde yer alan "herkes... kanun önünde eşittir” ifadesi temel önermeyi oluştururken, "dil, ırk, renk, cinsiyet, siyasi düşünce, felsefi inanç, din, mezhep ve benzeri sebeplerle ayrım gözetilmeksizin" ifadesi ise yan önermeyi oluşturmaktadır (Öden, 2003: 129-130). Söz konusu ilk önermeden yola çıkarak işverenin genel anlamda eşit davranma borcunun da bulunduğu görülmektedir. Ayrıca Yargıtay'ın eşit davranma borcuna ilişkin vermiş olduğu kararlarda Anayasa madde 10 haricinde, "ücrette adaletin sağlanması" başlıklı madde 55'e de dayanıldığı görülmektedir.

Anayasa madde $11^{\prime}$ de, Anayasa'da yer alan düzenlemelerin özel hukuk kişileri arasında da uygulanacağı hüküm altına alınmıştır. Temelinde ayrımcı bir sebep bulunmaksızın aynı nitelik, kıdem ve statüye sahip aynı durumdaki işçiler arasında farklılık yaratmaması, benzer olanlara benzer davranılması, keyfi veya haklı görülmeyecek nedenlerle farklı işlem yapılamaması genel anlamda eşit davranma borcunun konusunu oluşturmaktadır (Doğan Yenisey, 2005: 978-979). Ücret, ikramiye, prim, sosyal yardım vb. gibi haklar; işverenin yönetim yetkisi kapsamında giriş çıkış kontrolü yapması, sigara yasağı, fazla çalışma yaptırılması, angarya işlerin verilmesi, işin dağıtımı, iş ve işyerinin belirlenmesi, disiplin cezası, meslekte yükselme gibi hususlar genel anlamda eşit davranma borcunun kapsamına girmektedir. Ancak örneğin, ücretlerde yapılan farklılaştırma iş̧̧ilerin ırkı temelinde ise bu durumda artık ayrımcılık yasağı söz konusu olmalıdır. Diğer yandan farklı durumda olanlara adalet ve hakkaniyet gereği farklı işlem yapılması gerekiyor ve yapılmamışsa bu durumda da eşitlik ilkesinin ihlali söz konusudur (Bkz. Nazlı, 2016: 577). Dağıtıcı adalet ilkesi gereği işçilere sağlanacak haklar bakımından ehliyet, liyakat, yetenek, başarı gibi etkenler dikkate alınmalıdır (Süzek, 2019: 444; Yargıtay HGK'nın 29.09.2020 tarih ve 293/690 sayılı kararı, Lexpera).

\subsection{Genel Anlamda Eşit Davranma Borcunun Uygulama Koşulları}

Isş̧inin, işverenin genel anlamda eşit davranma borcuna dayanarak bir isteme hakkı elde etmesi, diğer işçilere daha iyi edimler sağlandığında ortaya çıkmaktadır (Tuncay, 1982: 59). Böylelikle iş̧̧inin farklı işleme tabi tutulduğu yönündeki iddiasının, benzer durumda bulunan farklı bir işçiyle yapılan karşılaştırmayı bünyesinde barındırdığını söylemek mümkündür (Doğan Yenisey, 2005: 984). İşverenin eşit davranma borcu nispi niteliği gereği, aynı ya da benzer durumdaki iş̧̧iler için söz konusudur (Süzek, 2019: 456). İşverenin eşit davranma borcuna uygun davranıp davranmadı̆̆ının tespiti için aralarında karşılaştırma yapılabilecek benzer durumda iş̧̧ilere gerek duyulmakta olup (Doğan Yenisey, 2005: 984) sonrasında işverenin bu iş̧̧ilere eşit-aynı şekilde davranıp davranmadığı değerlendirilebilecektir (Tuncay, 1982: 59; Yıldız, 2008: 30). Ancak karşıllaştırma yapılırken kıyas yapılacak iş̧̧inin belirlenmesinde sorunlar yaşanabilmektedir (Yıldız, 2008: 31). Bu nedenle doktrinde kıyas yapılabilecek iş̧̧inin belirlenmesi ve eşit davranma borcunun ihlal edilip edilmediğinin tespiti için bir takım koşulların varlığı öngörülmüştür. Söz konusu koşullar Yargıtay 9. HD’nin 2018 tarihli kararında "aynı işyerinin işçileri olma, işyerinde topluluk bulunması, kolektif uygulamanın varlığı, zamanda birlik ve iş sözleşmesiyle çalışmak" şeklinde ifade edilmiştir (Yargıtay 9. HD’nin 15.01.2018 tarih ve 2016-25313/156 sayılı kararı, Lexpera). İ̧veren işçileri arasında yapmış olduğu farklı uygulamayı hakılıaştıramadığı takdirde ise eşit davranma borcunu ihlal etmiş olacaktır. 


\subsection{Genel Anlamda Eşit Davranma Borcuna Aykırıı̆ı̆ın Sonuçları}

IK madde 5'te yar alan ayrımcılık tazminatı, yalnızca ayrımcılık halleri için öngörülmüş olup, genel anlamda eşit davranma borcunun ihlalinde uygulanmamaktadır. Nitekim Yargıtay 9. HD’nin 2018 tarihli bir kararında her eşit işlem borcuna aykırılık için ayrımcılık tazminatı öngörülmemiş olduğu, bu yaptırımın uygulanabilmesi için işçilerin ík madde 5'te mutlak olarak belirtilen dil, ırk, cinsiyet, siyasal düşünce vb. özellikleri bakımından ihlalin gerçekleşmesi gerektiği, somut olayda işçiler arasında eşit işlem borcuna aykırı olarak farklı ücret uygulaması meydana gelmiş ise de bu aykırılık belirtilen ayrımcılık hallerinden biri olmadığından ayrımcılık tazminatına hükmedilemeyeceği ifade edilmiştir (Yargıtay 9. HD’nin 20.02.2018 tarih ve 2016-22291/3576 sayılı kararı, Lexpera). Doktrindeki bir görüşe göre ayrımcılık yasağı dışında işverenin genel anlamda eşit davranma borcunu ihlal etmesi neticesinde de ayrımcılık tazminatına hükmedilmelidir (Keser, 2004: 26; Kaya, 2014: 255 vd.). Bizim de paylaştığımız diğer görüşe göre İK madde 5 uyarınca hükmedilecek bir tazminat yalnızca madde metninde sayılan ve ayrımcılık yasağı kapsamına giren hallerde söz konusu olabilecektir (Süzek, 2019: 459). Nitekim Yargıtay uygulaması da bu yönedir. Doktrinde işçinin ayrıca maddi ve manevi tazminat açma hakkının da bulunduğu savunulmaktadır (Mollamahmutoğlu/Astarlı/Baysal, 2014: 745). Genel anlamda eşit davranma borcunun ihlali halinde işçi eda davası açarak mahrum kaldığı ücret farkı, ücret ekleri, sosyal yardım, kıdeme bağlı haklar, vb. diğer hakları talep etme imkanı vardır (Tuncay, 1982: 220). İşverenin işe almada eşit davranma borcu olmadığı kabul edildiğinden bu döneme ilişkin talepler culpa in contrahendo sorumluluğa dayanılarak talep edilebilmektedir (Doğan Yenisey, 2006: 77; Sur, 2017: 41 ).

\section{SONUÇ}

Eşitlik ilkesinin iş hukukundaki görünümü olan işverenin geniş anlamda eşit davranma borcu; ayrımcılık yasağı ile işverenin genel anlamda eşit davranma borcu olarak 2 farklı olguyu bünyesinde barındırmaktadır. Ayrımcılık yasağı ile işverenin genel anlamda eşit davranma borcu ise gerek nitelikleri gerekse ihlal edilmelerinin sonuçları bakımından birbirlerinden ayrılmaktadırlar. Ayrımcılık yasağının konusunu temel hak ve özgürlükler kapsamında insanın insan olmasından kaynaklanan ve değiştirilemeyecek özellikleri ya da değiştirilmesi beklenemeyecek dünya görüşüne ilişkin fikirleri oluştururken, işverenin genel anlamda eşit davranma borcunun konusunu ücret, ikramiye, prim, sosyal yardım vb. gibi haklar ile işverenin yönetim yetkisi kapsamında olan hususlar oluşturmaktadır. İşverenin ayrımcılık yasağı hükümlerini ihlali halinde işçi, ayrımcılık tazminatı talep edebileceği gibi mahrum kaldığı hakları da talep etme imkanına sahiptir. Ayrıca işçi maddi ve manevi tazminat davası açabileceği gibi, Türkiye İnsan Hakları ve Eşitlik Kurumu Kanunu uyarınca ilgili Kurum’a başvurabilecek ve Türk Ceza Kanunu madde 122 uyarınca savcılığa suç duyurusunda bulunabilecektir. İşverenin genel anlamda eșit davranma borcunun ihlali halinde ise işçinin ayrımclık tazminatı talep etme hakkı olmayıp, mahrum kaldığını ileri sürdüğü ve emsal işçiye göre hesaplanacak olan haklarını talep etme imkanı bulunmaktadır.

\section{KAYNAKÇA}

Aktay, A. N., Arıcı, K., Saylan Kaptan, E. T. (2012). Iş Hukuku. 5. Baskı. Ankara: Gazi Kitabevi.

Baysal, U. (2010). İşverenin eşit davranma borcu ve iş sözleşmesinin feshinde uygulanması. Legal isGHD, 25: 60-99.

Çelik, N., Caniklioğlu N., Canbolat, T. (2019). İş Hukuku Dersleri. 32. Bası. İstanbul: Beta.

Doğan Yenisey, K. (2006). İş kanununda eşitlik ilkesi ve ayrımcılık yasağı, Çalışma ve Toplum, 4: 63-82.

Doğan Yenisey. K. (2005). Eşit davranma ilkesinin uygulanmasında metodoloji ve orantılılık ilkesi. Legal iSGHD, 7: 973-1003.

Kandemir, M., Yardımcıoğlu, D,. (2014). İş hukukunda eşitlik ilkesi. DÜHFD, 19(30-31): 1-44.

Kaya, P. A. (2014). Çalışma Hukukunda Eşitlik ve Ayrımcılık, Ankara: Siyasal Kitabevi.

Kayaalp, D. (2019). Türkiye insan hakları ve eşitlik kurumu kanunu ile getirilen ayrımcılık yasağı istisnalarının iş hukukundaki görünümü üzerine genel bir değerlendirme. ASBÜHFD, 1(1): 67-107.

Keser, H. (2004). 4857 sayılı İ'na göre işverenin iş sözleşmesi yapma ve iş ilişkilerinde eşit işlem yapma yükümlülükleri ve bunlara aykırı davranması durumunda karşılaşacağı yaptırımlar. Kamu-işs, 7(3): 1-37.

Mollamahmutoğlu H., Astarlı, M., Baysal, U. (2014). İ̧̧ Hukuku. 6. Bası. Ankara: Turhan Kitabevi.

Mollamahmutoğlu, H., Muhittin A., Ulaş B. (2019). İş Hukuku Ders Kitabı Cilt 1: Bireysel İş Hukuku. 3. Baskı. Ankara: Lykeion.

Nazlı, S. (2016). İş Kanunu'nda düzenlenen eşit davranma ilkesi ve uygulama sorunları üzerine değerlendirmeler. İstanbul Hukuk Mecmuası, 74(2): 571-586.

Öden, M. (2003). Türk Anayasa Hukukunda Eşitlik İlkesi, Ankara: Yetkin.

Sarıbay Öztürk, G. (2017). Türkiye insan hakları ve eşitlik kurumu kanunu sonrasında iş sözleşmesinin sona ermesinde yaşlı ayrımcılığı. Sicil iş Hukuku Dergisi, 37: 114-141.

Sur, M. (2017). İş ilişkisinde eşitlik ilkesi ve ayrımcılık yasağı. Sicil İş Hukuku Dergisi, 37: 33-51.

Süzek, S. (2019). İş Hukuku. 18. Bası. İstanbul: Beta.

Taşdemir, Y. (2020). İş hukukunda genetik ayrımcılık yasağı. DEÜHFD, 22(2): 946-990. 
Tuncay, A. C. (1982). İ̧̧ Hukukunda Eşit Davranma Illkesi, İstanbul: İstanbul Üniversitesi Yayınları.

Tunçomağ, K., Centel, T. (2015). İş Hukukunun Esasları. 7. Baskı. İstanbul: Beta.

Ulucan, D. (2013). Eşitlik ilkesi ve pozitif ayrımclık. DEÜHFD, 15: 369-383.

Ünal, C. (2018). İş Hukukunda Yaş Ayrımcılığı, İstanbul: On İki Levha Yayıncılık.

Yıldız, G. B. (2008). İ̧verenin Eşit İşlem Yapma Borcu, Ankara: Yetkin.

www.lexpera.com.tr

www.kazanci.com.tr 